\title{
THE JOURNAL

\section{CONTENTS}

Arnaldo Momigliano .

J. S. Richardson, The Purpose of the Lex Calpurnia de repetundis . . . . . . . 1

Brian Campbell, Teach Yourself how to be a General . . . . . . . 13

Brent D. Shaw, The Age of Roman Girls at Marriage: Some Reconsiderations 30

Maria Wyke, Written Women: Propertius' Scripta Puella ～～～～～～～～～～. . 47

David Johnston, Three Thoughts on Roman Private Law and the Lex Irnitana 62

Jean-Louis Mourgues, The So-called Letter of Domitian at the End of the Lex Irnitana . $\quad 78$

R. R. R. Smith, The Imperial Reliefs from the Sebasteion at Aphrodisias $\quad$. $\quad$. $\quad$. 88

C. P. Jones, Stigma: Tattooing and Branding in Graeco-Roman Antiquity ～～～～. . 139

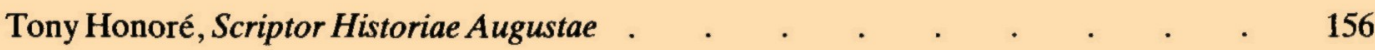

\section{REVIEW ARTICLES}

Andrew Burnett, The Changing Face of Republican Numismatics

(M. H. Crawford, Roman Republican Coinage. 1. Introduction and Catalogue.

2. Studies, Plates and Indexes; id., Coinage and Money under the Roman Republic.

Italy and the Mediterranean Economy)

R. G. M. Nisbet, Pyrrha among Roses: Real Life and Poetic Imagination in Augustan Rome

(Jasper Griffin, Latin Poets and Roman Life)

REVIEWS AND NOTICES OF PUBLICATIONS—see back of cover.

PUBLISHED BY THE SOCIETY FOR THE PROMOTION OF ROMAN STUDIES AT THE OFFICE OF THE SOCIETY 31-34 GORDON SQUARE WC1H OPP TO BE OBTAINED THROUGH ALL BOOKSELLERS AND FROM THE SOCIETY 


\section{Society for the Promotion of Roman Studies}

\section{ANNUAL SUBSCRIPTION $£ 15.00$}

The Society promotes the study of the history, archaeology, literature and art of Rome, Italy and the Roman Empire down to about A.D. 700.

\section{PUBLICATIONS OF THE SOCIETY}

The Society publishes the Journal of Roman Studies and Britannia annually. The JRS contains articles and reviews of books and deals with the Roman world generally. Britannia also contains articles and reviews but specifically on Roman Britain. Members of the Society may receive either the JRS or Britannia for $£ 15.00$ or both for $£ 26.00$. Subscribing Libraries pay $£ 16.00$ for each publication and non-members $£ 21.00$. The Society's publications in the JRS Monograph series are: No. 1, Aphrodisias and Rome, No. 2, Excavations at Sabratha, 1948-1951, No. 3, Arable Cultivation in Roman Italy, and (forthcoming) No. 4, Monuments from the Aezanitis (MAMA IX) and No. 5 Aphrodisias in Late Antiquity. In the Britannia Monograph series the following are available: No. 1, Roman Mosaics in Britain, No. 2, Skeleton Green (A Late Iron Age and Romano-British site), No. 3, Wall-Painting in Roman Britain, No. 4, Vindolanda: The Latin Writing Tablets, No. 5, Silchester Defences 1974-80, No. 6, Inchtuthil, The Roman Legionary Fortress, No. 7, Baldock, The Excavation of a Roman and pre-Roman Settlement, 1968-72, No. 8, Longthorpe II: The Military Works-Depot: An Episode in Landscape History, and (forthcoming) No. 9, Strageath. For prices please apply to the Secretary.

\section{THE LIBRARY AND SLIDE COLLECTION}

The Society together with the Hellenic Society and in association with the Institute of Classical Studies of the University of London maintains a Joint Library of some 60,000 volumes with over 450 current periodicals. This is one of the principal collections for the study of the ancient world. The Slide Collection includes over 5,500 single colour transparencies and a number of sets and filmstrips with descriptive texts by leading authorities. Members resident in, or visiting the United Kingdom may borrow the Societies' books and slides, either by personal visit or by post. Books which belong to the Institute of Classical Studies may be consulted but not borrowed.

All communications regarding books and slides should be made to the Librarian or Keeper of Slides, Hellenic and Roman Societies, 31-34 Gordon Square, London WC1H0PP.

\section{MEETINGS}

Meetings for the reading and discussion of papers are held in London and others are arranged with local branches of the Classical Association outside London. A Programme of Meetings is circulated to U.K. members in the autumn.

\section{MEMBERSHIP AND SUBSCRIPTIONS}

The Society consists of life members, annual members, student-associates (U.K. and Commonwealth only), and subscribing libraries and institutions. Annual Subscription is $£ 15.00$ (for either the JRS or Britannia, $£ 26.00$ for both). Student associate members pay $£ 7.50$. Life membership for those members of five years’ standing and sixty-five years of age or over is $£ 75.00$. Libraries pay $£ 16.00$ for each publication. Please write for further details to the Secretary, Roman Society, 31-34 Gordon Square, London WC1H 0PP.

\section{BOOKS FOR REVIEW}

These must be sent to the Librarian, Hellenic and Roman Societies, 31-34 Gordon Square, London WC1H 0PP. 


\section{THE JOURNAL OF ROMAN STUDIES}


WITH ACKNOWLEDGMENTS TO THE BRITISH ACADEMY AND THE CAMBRIDGE H. A. THOMAS FUND 


\title{
THE JOURNAL OF ROMAN STUDIES
}

\author{
VOLUME LXXVII
}

PUBLISHED BY THE SOCIETY FOR THE PROMOTION OF ROMAN STUDIES AT THE OFFICE OF THE SOCIETY, 31-34 GORDON SQUARE, LONDON WCIH OPP 
Printed in Great Britain by

W. S. Maney and Son Limited

Hudson Road Leeds 9

(C)

The Society for the Promotion of Roman Studies 


\section{CONTENTS}

Arnaldo Momigliano

J. S. Richardson, The Purpose of the Lex Calpurnia de repetundis

Brian Campbell, Teach Yourself how to be a General

Brent D. Shaw, The Age of Roman Girls at Marriage: Some Reconsiderations

Maria Wyke, Written Women: Propertius' Scripta Puella

David Johnston, Three Thoughts on Roman Private Law and the Lex Irnitana

Jean-Louis Mourgues, The So-called Letter of Domitian at the End of the Lex

Irnitana

R. R. R. Smith, The Imperial Reliefs from the Sebasteion at Aphrodisias .

C. P. Jones, Stigma: Tattooing and Branding in Graeco-Roman Antiquity

TONY HonORE, Scriptor Historiae Augustae .

PAGE

\section{REVIEW ARTICLES}

Andrew Burnett, The Changing Face of Republican Numismatics

(M. H. Crawford, Roman Republican Coinage. I. Introduction and Catalogue. 2. Studies, Plates and Indexes; id., Coinage and Money under the Roman Republic. Italy and the Mediterranean Economy)

R. G. M. Nisbet, Pyrrha among Roses: Real Life and Poetic Imagination in Augustan Rome (Jasper Griffin, Latin Poets and Roman Life)

\section{REVIEWS AND NOTICES OF PUBLICATIONS (in alphabetical order)}

Alföldi, M. R. (Ed.), Studien zu Fundmünzen der Antike. 2. Aufsätze (by R. Reece) . Ammianus Marcellinus, Histoire. Tome v (Livres XXVI-XXvIII). Ed. M.-A. Marié (by H. Forte)

Anderson, G., Ancient Fiction: the Novel in the Graeco-Roman World (by C. Gill)

Die antiken Sarkophagenreliefs. 5, iv. Jahreszeiten-Sarkophage: Entwicklung und Ikonographie des Motivs der vier Fahreszeiten auf kaiserzeitlichen Sarkophagen und Sarkophagdeckeln (by S. Walker)

Baldini, A., Ricerche sulla storia di Eunapio di Sardi: problemi di storiagrafia tardopagana (by J. M. Alonso-Núñez) .

Beard, M. and Crawford, M., Rome in the Late Republic: Problems and Interpretations (by N. Purcell)

Bianchi, L., Le stele funerarie della Dacia: un espressione di arte romana periferica (by A. G. Poulter)

Bintliff, J. (Ed.), European Social Evolution: Archaeological Perspectives (by G. Barker)

Bishop, J. D., Seneca's Daggered Stylus: Political Code in the Tragedies (by H. M. Hine).

Bonfante, L. (Ed.), Etruscan Life and Afterlife: a Handbook of Etruscan Studies (by N. Spivey) .

Boyle, A. J. (Ed.), Seneca Tragicus: Ramus Essays on Senecan Drama (by H. M. Hine).

Brancacci, A., Rhetorike Philosophousa: Dione Crisostomo nella cultura antica $\dot{e}$ bizantina (by C. P. Jones)

Braund, D., Rome and the Friendly King. The Character of the Client Kingship (by S. Mitchell)

Christ, K., Römische Geschichte und deutsche Geschichtswissenschaft (by T. Wiedemann) 
Corpus Cultus Equitis Thracii (CCET). 2. Gočeva, Z. and Oppermann, M., Monumenta inter Danubium et Haemum reperta. 2. Regio oppidi Tărgovište, Abrittus et vicinia, Sexaginta Prista et vicinia, Nicopolis ad Istrum et vicinia, Novae (by A. G. Poulter)

Cotton, M. A. and Métraux, G. P. R., The San Rocco Villa at Francolise (by J. Percival)

Cugusi, P., Aspetti letterari dei Carmina latina epigraphica (by N. Horsfall) $\cdot \cdot \cdot \cdot$

Dagron, G., La Romanité chrétienne en orient: héritages et mutations (by R. D. Scott)

Develin, R., The Practice of Politics at Rome $366-167$ в.c. (by J. Briscoe) $\cdot \dot{*} \quad \cdot \quad \cdot$

Di Porto, A., Impresa collettiva e schiavo 'manager' in Roma antica (II sec. a.C. - II sec.d.C.) (by J. Percival)

Dilke, O. A. W., Greek and Roman Maps (by R. J. A. Talbert)

Este I. Le necropoli Casa di Ricovero, Casa Muletti Prosdocimi e Casa Alfonsi (by M. H. Crawford)

Excavations at Carthage: The British Mission. I. The Avenue du Président Habib Bourguiba, Salammbo. i. The Site and Finds other than Pottery. ii. The Pottery and other Ceramic Objects from the Site (by J. H. Humphrey).

Fleischer, R., Der Klagefrauensarkophag aus Sidon (by S. Walker) .

Gebhart, H. and Kraft, K., Die Fundmünzen der römischen Zeit in Deutschland. 4. Rheinland-Pfalz. 5. Montabaur. 6. Nordrhein-Westfalen. I, I. Stadt Köln (by R. Reece)

Geiger, J., Cornelius Nepos and Ancient Political Biography (by T. P. Wiseman)

Green-Pedersen, N. J., The Tradition of the Topics in the Middle Ages: the Commentaries on Aristotle's and Boethius' 'Topics' (by M. Gibson)

Grziwotz, H., Das Verfassungsverständnis der römischen Republik: ein methodischer Versuch (by R. Seager) .

Hadot, I., Arts libéraux et philosophie dans la pensée antique (by E. Rawson) . ·

Haynes, S., Etruscan Bronzes (by J. Swaddling)

Henry, D. and E., The Mask of Power: Seneca's Tragedies and Imperial Rome (by H. M. Hine) .

Hinard, F., Les Proscriptions de la Romé républicaine (by A. Lintott)

Howgego, C. J., Greek Imperial Countermarks: Studies in the Provincial Coinage of the Roman Empire (by S. Mitchell)

Humphrey, J., Roman Circuses. Arenas for Chariot Racing (by R. J. A. Wilson) -

Jacques, F., Le Privilège de liberté. Politique impériale et autonomie municipale dans les cités de l'occident romain $\left(166_{1-244}\right)$ (by $\mathrm{H}$. Galsterer)

Kneppe, A. and Wiesehöfer, J., Friedrich Münzer: ein Althistoriker zwischen Kaiserreich und Nationalsozialismus. Zum 20. Oktober 1982. Mit einem kommentierten Schriftenverzeichnis von H.-F. Drexhage (by T. Wiedemann).

Koch, G. and Sichtermann, H., Römische Sarkophage (by S. Walker)

Kuntze, C., Zur Darstellung des Kaisers Tiberius und seiner Zeit bei Velleius Paterculus (by B. Levick)

Laidlaw, A., The First Style in Pompeii: Painting and Architecture (by R. Ling) •

The Letters of St Cyprian of Carthage. Trans. and ed. G. W. Clarke. I. Letters $1-27$. 2. Letters 28-54-3. Letters 55-66 (by A. Lenox-Conyngham) · . $\cdot$.

Leveau, P., Caesarea de Maurétanie: une ville romaine et ses campagnes (by $\mathrm{S} . \mathrm{P}$. Ellis) .

Levick, B., The Government of the Roman Empire: a Sourcebook (by G. Burton) .

López Rodríguez, J. R., Terra sigillata hispánica tardía decorada a molde de la Peninsula Ibérica (by M. H. Crawford) .

McCulloch, H. Y., Jr., Narrative Cause in the Annals of Tacitus (by J. M. AlonsoNúñez)

MacDonald, W. L., The Architecture of the Roman Empire. in. An Urban Appraisal (by J. Carter)

McGing, B. C., The Foreign Policy of Mithridates VI Eupator, King of Pontus (by J. W. Rich)

Mann, M., The Sources of Social Power. I. A History of Power from the Beginning to A.D. 1760 (by G. Woolf) 
Mayet, F., Les céramiques sigillées hispaniques: contribution à l'histoire economique de la péninsule ibérique sous l'empire romain (by M. H. Crawford)

Meiggs, R., Trees and Timber in the Ancient Mediterranean World (by K. D. White)

Overbeck, B., Geschichte des Alpentheintals in römischer Zeit auf Grund der archäologischen Zeugnisse. 1. Topographie, Fundvorlage und historische Auswertung (by J. F. Drinkwater) .

Pauli, L., The Alps: Archaeology and Early History (by J. F. Drinkwater) .

Poma, G., Tra legislatori e tiranni: problemi storici e storiografici sull'età delle XII tavole (by J. M. Alonso-Núñez)

Posch, S., P. Ovidius Naso. Tristia I: Interpretationen. I. Die Elegien $1-4$ (by S. Hinds)

Pratt, N. T., Seneca's Drama (by H. M. Hine)

Properzio. Il libro terzo delle elegie. Introduzione, testo e commento. Ed. P. Fedeli (by M. Hubbard)

Rainini, I., Il santuario di Mefite in Valle d'Ansanto (by J. R. Patterson)

Rawson, E., Intellectual Life in the Late Roman Republic (by P. R. Hardie)

Renger, C., Aeneas und Turnus. Analyse einer Feindschaft (by D. C. Feeney) . .

Rousseau, P., Pachomius: the Making of a Community in Fourth-century Egypt (by S. N. C. Lieu)

Saller, R. P., Personal Patronage under the Early Empire (by G. Woolf) . .

Schürer, E., The History of the Fewish People in the Age of fesus Christ (175 B.C.-A.D. 135). and ed. rev. G. Vermes, F. Millar and M. Goodman (by B. Isaac) . .

Seneca's Thyestes. Ed. R. J. Tarrant (by H. M. Hine)

Seneca's Troades. Ed. E. Fantham (by H. M. Hine)

Sidi Khrebish. Excavations at Sidi Khrebish Benghazi (Berenice). III, I. The Fine Pottery. III, 2. The Lamps (by M. G. Fulford).

Stack, F., Pope and Horace: Studies in Imitation (by P. Wilson)

Stutzinger, D., Die frühchristlichen Sarkophagreliefs aus Rom: Untersuchungen zur Formveränderung im 4. Fahrhundert n. Chr. (by S. Walker) . . . .

Swaddling, J. (Ed.), Italian Iron Age Artefacts in the British Museum: Papers of the Sixth British Museum Classical Colloquium (by N. Spivey)

Teitler, H. C., Notarii and Exceptores: an Inquiry into Role and Significance of Shorthand Writers in the Imperial and Ecclesiastical Bureaucracy of the Roman Empire (from the Early Principate to c. 450 A.D.) (by J. R. Martindale)

Thuillier, J.-P., Les feux athlétiques dans la civilisation étrusque (by N. Spivey) . van Berchem, D., Les Routes et l'histoire: études sur les Helvètes et leurs voisins dans l'empire romain (by J. F. Drinkwater)

Walser, G., Summus Poeninus: Beiträge zur Geschichte des Grossen St. Bermhardpasses in römischer Zeit (by J. F. Drinkwater)

Wightman, E. M., Gallia Belgica (by G. Herring) .

Wille, K., Die Versur: eine rechtshistorische Abhandlung über die Zinskapitalisierung im alten Rom (by D. E. L. Johnston)

Winkler, J. J., Auctor and Actor: a Narratological Reading of Apuleius's Golden Ass (by H. E. Elsom) .

Wiseman, T. P., Catullus and his World: a Reappraisal (by H. P. Syndikus) . .

Zwierlein, O., Senecas Hercules im Lichte kaiserzeitlicher und spätantiker Deutung. Mit einem Anhang über 'tragische Schuld' sowie Seneca-Imitationen bei Claudian und Boethius (by H. M. Hine)

List of Works Received

Proceedings of the Society 
viii

\section{LIST OF PLATES}

Maria Wyke, Written Women: Propertius' Scripta Puella

Plate $\mathrm{I} \quad$ Drawing by $\mathrm{H}$. Roux after a Pompeian Wall-painting. L. Barré, Herculanum et Pompéi (186I), II pl. 35

Jean-Louis Mourgues, The So-called Letter of Domitian at the End of the Lex Irnitana

Plate II The Lex Irnitana, Tablet X, column C

R. R. R. Smith, The Imperial Reliefs from the Sebasteion at Aphrodisias

(Photographs: Plates III, V, 2, VII, I, 3, 4, IX, 2, 3, XI, I, XIII, 2-4, XV, I-3, XVII, I, 3, XIX, I , XXI, I-4, XXIII, I-3, XXV, 3-4, XXVI, I-2 author; IV, V, I, 3, vI, VII, 2, VIII, IX, I, X, XI, 2, XII, XIII, I, XIV, XVI, XVII, 2, XVIII, XIX, 2-3, XX, xxII, XxIII, 4, xxIv, XXV, I-2 M. Ali Düğenci)

Plate III View of portico buildings of Sebasteion, looking west, from Temple terrace towards Propylon

Plate IV No. I, Augustus with Nike and trophy

Plate v (I) Augustus from no. I

(2) Top of no. I

(3) Augustus from no. I

(4) Bust of Augustus. Copenhagen 6ro. From Poulsen, PR I, pl. XLviII

Plate vi No. 2, Augustus by land and sea

Plate vil (I) $-(2)$ Augustus from no. 2

(3) Detail of land figure from no. 2

(4) Augustus' torso from no. 2

Plate viII No. 3, Claudius and Agrippina

Plate IX (I) Agrippina from no. 3

(2) Claudius from no. 3

(3) Agrippina from no. 3

(4) Head of Claudius with corona civica. Copenhagen 648. From Poulsen, $P R$, pl. Xcvir

Plate $X \quad$ No. 4 , Germanicus with captive

Plate XI (I) $-(2)$ Germanicus from no. 4

(3)-(4) Head of Germanicus (in 'Leptis-Béziers' type). Stuttgart 65/10.

From U. Hausmann, Römerbildnisse (I975), figs I I and I 3

Plate XII No. 5, Imperator with Roman People or Senate

Plate XIII (1)-(2) Imperator from no. 5

(3)-(4) Roman People or Senate from no. 5

Plate XIV No. 6, Claudius and Britannia

Plate Xv (1)-(2) Claudius from no. 6

(3) Base from no. 6, Claudius and Britannia

Plate XvI No. 7 , Nero and Armenia

Plate XvII

(1)-(2) Fragmentary head of Nero from no. 7

Plate XVIII

(3) Base from no. 7, Nero and Armenia

Plate XIX

No. 8, Unfinished Imperator (Tiberius?) with captive

Plate $\mathrm{xx}$

(I) $-(3)$ Tiberius (?) from no. 8

Plate XXI

No. 9, Two princes

(1)-(2) Prince A

(3)-(4) Prince B

Plate XxII No. IO, Empress sacrificing (Livia?)

Plate XXIII (I) Attendant from no. Io, with face fragment

(2)-(4) Fragmentary head (Livia?) from no. Io

Plate xxiv No. I I, Nero and Agrippina

Plate XXv (I) Nero from no. II

(2) Agrippina from no. I I

(3)-(4) Nero from no. I I

Plate xxvi (I) Nero from no. I I

(2) Agrippina from no. I I

(3) Head of Nero (second or accession type). Capitoline Mus. 418.

From FZ I, pl. 17

(4) Head of Agrippina the Younger. Copenhagen 636. From Poulsen, $P R$ I, pl. cIII 


\section{LIST OF FIGURES IN THE TEXT}

PAGE

Brent D. Shaw, The Age of Roman Girls at Marriage: Some Reconsiderations

$\left.\begin{array}{ll}\text { Fig. I Age distribution of funerary commemorations } \\ \text { Fig. } 2\end{array}\right\}$ busbands vs Parents as commemorators 30 and $3^{I}$

R. R. R. Smith, The Imperial Reliefs from the Sebasteion at Aphrodisias

Fig. I Plan of Sebasteion

Fig. 2 Restored elevation and section of Room 3 of South Portico 92

Fig. 3 Sketch of Sebasteion porticoes restored, looking west from Temple to Propylon

Fig. 4 Top of no. I, Augustus with Nike IOI

Fig. 5 Top of no. 2, Augustus, Land, and Sea $\quad 104$

$\begin{array}{ll}\text { Fig. } 6 \text { Top of no. 3, Claudius and Agrippina } & 107\end{array}$

Fig. 7 Top of no. 5, Imperator with Roman Senate or People I I3

Fig. 8 Top of no. 6, Claudius and Britannia $\quad$ I 5

Fig. 9 Fringe arrangements of no. 8 (left), and Augustus's main type (right) I 22

Fig. Io Top of no. 9, Two Princes $\quad$ I23

Fig. I I Agrippina's hairstyle, no. I I 13 I

Fig. I2 Possible scheme of reliefs above Rooms I-3, at east end of South Portico I 33

Fig. I3 Possible scheme of reliefs of third storey of Rooms 5-7 I33 


\title{
SOCIETY FOR THE PROMOTION OF ROMAN STUDIES OFFICERS AND COUNCIL, I $987-88$
}

\author{
President \\ DR. JOYCE M. REYNOLDS, F.B.A., F.S.A. \\ Vice-Presidents \\ PROFESSOR B. ASHMOLE, C.B.E., M.C., F.B.A., Hon \\ DR. BARBARA LEVICK, F.S.A \\ PROFESSOR F. G. B. MILLAR, F.B.A., F.S.A. \\ DR. J. N. L. MYRES, LL.D., D.LITT., D.LIT., F.B.A. \\ F.S.A. \\ PROFESSOR A. E. ASTIN \\ MRS. M. BENNETT
PROFESSOR ERIC BIRLEY, M.B.E., F.B.A., F.S.A. \\ MR. G. C BOON F SA \\ MR.G.C. BOON, F.S.A. \\ PROFESSOR P.A.BRUNT, F.B.A. \\ PROFESSOR R. G. M. NISBET, F.B.A. \\ MR. P.R. ODGERS, C.B. \\ SIR HILTON POYNTON, G.C.M.G. \\ PROFESSOR A L F RIVET F B A F S.A. \\ PROFESSOR J.K. S. ST JOSEPH, C.B.E., SC.D., LL.D. \\ PH.D., F.B.A., F.S.A. \\ PROFESSOR M. H. CRAWFORD, F.B.A \\ PROFESSOR J. A. CROOK \\ PROFESSOR S. S. FRERE, C.B.E., F.B.A., F.S.A. \\ OFESSOR MICHAEL GRANT, C.B.E., LITT.D. \\ F.S.A \\ PROFESSOR W. F. GRIMES, C.B.E., D.LITT ., F.S.A. \\ PROFESSOR O. SKUTSCH, HON. F.B.A. \\ MR. A. N. SHERWIN-WHITE, F.B.A. \\ SIR RONALD SYME, O.M., D.LITT., F.B.A. \\ PROFESSOR E. A. THOMPSON, F.B.A. \\ PROFESSOR M. TODD, F.S.A. \\ PROFESSOR F. W. WALBANK, F.B.A. \\ PROFESSOR K. HOPKINS, F.B.A. \\ PROFESSOR E. J. KENNEY, F.B.A. \\ PROFESSOR J. J. WILKES, F.S.A. \\ MR. F. A. LEPPER, F.S.A
}

\section{Ordinary Members of Council}

Elected $y_{\text {une }} 198_{5}$.
DR. SHIRLEY A. BARLOW
DR. T. F. C. BLAGG, F.S.A.
DR. D. C. BRAUND
MR.P. CRUMMY, F.S.A.
MR.P. DOBSON, F.S.A.
PROFESSOR J.C.MANN, F.S.A.
DR. D. RATHBONE
DR. R. REECE, F.S.A.

$\quad$ Elected fune 1986
MR. P. T. BUCKLEY
MISS M. HALL
DR. JILLD. HARRIES
DR. SUE MARTIN
MR. J. MURRELL
MR. J. PATERSON
DR. M. P. SPURR

Elected Yune 1987

MR. A. L. CUBBERLEY

MR.A.L. CUBBERLEY

PROFESSOR H. MACL.CURRIE

PROFESSOR R. M.

DR. NICOLA MACKIE

MR. G.S. MAXWELL

MR. M. ROUECH

DR. I. M. STEAD

\section{Honorary Members of the Society}

\begin{abstract}
PROFESSOR E. BADIAN
PROFESSOR T.R.S. BROUGHTON

PROFESSOR A. CHASTAGNOL

PROFESSOR E. GABBA

PROFESSOR E. GJERSTAD

PROFESSOR I HEURGON PROFESSOR M. KASER
\end{abstract}

\section{Hon. Treasurer}

MR. J. H. C. LEACH
Hon. Secretary

MISS E. RAWSON

Secretary

MRS. P. GILBERT, B.A.

Auditors

SHIPLEY, BLACKBURN

Joint Library

\section{Hon. Librarian
MR. J. C. B. LOWE \\ Hon. Librarian
MR. J. C. B. LOWE \\ PROFESSOR M. H. CRAWFORD \\ MR. C. M. DANIELS \\ DR. D. P. FOWLER \\ PROFESSOR S. FRERE}

\section{Keeper of Slides Collection}

MISS C. GRANDE, B.A.

\section{Editorial Committee}

\section{Editor, $7 R S$ : PROFESSOR AVERIL CAMERONan: PROFESSOR F. G. B. MILLAR}

Editor, Briannia: PROFESSOR M. TODD

Review Editor: DR. J. A. NORTH $\quad$ Review Editor: DR. J. P. WILD, F.S.A.

MR. R. H. A. JENKYNS

DR. O. MURRAY

PROFESSOR J. J. WILKES

\section{Librarian}

Editorial Assistant, $7 R S:$ DR. HELEN COCKLE

Editorial Assistant, Britannia: DR. LYNN PITTS

and with the co-operation of

MR. F. A. LEPPER, SIR RONALD SYME and PROFESSOR F. W. WALBANK Editors, Roman Britain Survey: PROFESSOR S. S. FRERE, MR. M. W. C. HASSALL, F.S.A
DR. R. S. O. TOMLIN

Contributions to the $\mathcal{Y R S}$ should be sent to Professor averil Cameron. The Editor, foumal of Roman Studies, King's College London, Strand, London WC2 $2{ }_{2}$ LS.

Contributions to Britannia should be sent to PROFESSOR M. TODD, The Editor, Britannia,

Department of Archaeology, University of Exeter, Queen's Building, Queen's Drive, Exeter $\mathrm{EX}_{4} 4 \mathrm{QH}$.

Books for review for both the $\mathcal{Y} R$ and Britannia must be sent to The Librarian, Joint Library, Hellenic and Roman Societies, $31-34$ Gordon Square, London, WC 1 H OPP.

(C) Society for the Promotion of Roman Studies 1987. All Rights Reserved. 